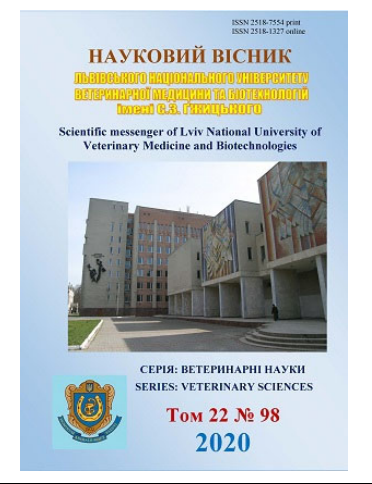

UDC 57.06:578.22:597

\author{
Науковий вісник Дьвівського національного університету \\ ветеринарної медицини та біотехнологій імені С.3. Гжицького. \\ Серія: Ветеринарні науки
Scientific Messenger of Lviv National University of Veterinary Medicine and Biotechnologies. \\ Series: Veterinary sciences
}

\title{
Modern taxonomy of viruses of vertebrates
}

\author{
O. S. Kalinina
}

Stepan Gzhytskyi National University of Veterinary Medicine and Biotechnologies Lviv, Ukraine

\section{Article info}

Received 20.04.2020 Received in revised form 25.05 .2020 Accepted 26.05.2020

Stepan Gzhytskyi National University of Veterinary Medicine and Biotechnologies, Pekarska Str., 50, Lviv, 79010, Ukraine. Tel.: +38-096-483-67-86 E-mail:kalininaos@ukr.net
Kalinina, O. S. (2020). Modern taxonomy of viruses of vertebrates. Scientific Messenger of Lviv National University of Veterinary Medicine and Biotechnologies. Series: Veterinary sciences, 22(98), 113-118. doi: 10.32718/nvlvet9820

The modern taxonomy of viruses of vertebrates is presented according to the information of ICTV issue 07.2019, ratification 03.2020. The leading criteria of taxonomy of viruses are named: type and structure of viral genome, mechanism of replication and morphology of virion. The periods of formation of taxonomic ranks of viruses are characterized: in 1966-1970 genera of viruses were formed, in 1971-1975 - families and subfamilies, since 1990 - orders, in 2018-2019 - realms, kingdoms, phylums, subphylums, classes, suborders, subgeneres. The nomenclature of viruses is described. Viruses belong to the Viruses domain. Viruses of vertebrates (1878 species) belong to 4 realms, 5 kingdoms, 10 phylums, 2 subphylums, 20 classes, 26 orders, 3 suborders, 45 families (of which 15 -DNA-genomic and 30-RNA-genomic), 33 subfamilies, 345 genera and 49 subgenera. Taxonomic ranks of DNA- and RNA-genomic viruses of vertebrates are described. The DNA-genome family Anelloviridae and the unclassified RNA-genomic genus Deltavirus are not included in any realm. The family Birnaviridae is not classified within the kingdom Orthornavirae. The family of DNA-genomic Hepadnaviridae is included in the realm of RNA-containing viruses Riboviria on the grounds that the replication of hepadnaviruses occurs through the stage of RNA on the principle of reverse transcription, as in the family Retroviridae. The main taxonomic features of DNA- and RNAgenomic viruses of vertebrates are described: type and structure of viral genome (DNA or RNA, number of strands, conformation, fragmentation, polarity), shape and size of virions, presence of outer lipoprotein shell, type of capsid symmetry (spiral, icosahedral). Some families, in addition to viruses of vertebrates, contain viruses of invertebrates and plants, in particular: families Poxviridae, Iridoviridae, Parvoviridae, Circoviridae, Smacoviridae, Genomoviridae, Rhabdoviridae, Nyamiviridae, Peribunyaviridae, Phenuiviridae, Nairoviviridae, Nodaviridae, Reoviridae and Birnaviridae - viruses of insects; families Genomoviridae, Rhabdoviridae, Phenuiviridae and Reoviridae - viruses of plants; family Nyamiviridae - viruses of nematodes, cestodes, sipunculides and echinoderms; family Rhabdoviridae - viruses of nematodes; family Reoviridae - Eriocheir sinensis reovirus; family Birnaviridae - viruses of tellines and rotifers.

Key words: viruses, taxonomy, taxonomic ranks and traits, DNA-genomic, RNA-genomic, ICTV.

\section{Новітня таксономія вірусів хребетних}

\author{
О. С. Калініна
}

Львівський національний університет ветеринарної медицини та біотехнологій імені С. 3. Гжиџького, м. Львів, Украӥна

Подано сучасну таксономію вірусів хребетних за інформацією МКТВ випуску 07.2019 р., ратифікаиія 03.2020 р. Названо провідні критерії таксономії вірусів: тип і структура вірусного геному, механізм реплікаиії та морфологія віріона. Охарактеризовано періоди формування таксономічних рангів вірусів: у 1966-1970 рр. сформовано роди вірусів, у 1971-1975 рр. - родини і підродини, з 1990 р. - порядки, у 2018 - 2019 рр. - регіони, иарства, типи, підтипи, класи, підпорядки, підроди. Описано номенклатуру вірусів. Віруси належсать до домену Viruses. Віруси хребетних (1878 видів) входять до 4 регіонів, 5 иарств, 10 типів, 2 підтипів, 20 класів, 26 порядків, 3 підпорядків, 45 родин (з яких 15 - ДНК-геномні та 30 - РНК-геномні), 33 підродин, 345 родів і 49 підродів. Описано таксономічні ранги ДНК- $і$ РНК-геномних вірусів хребетних. Родина ДНК-геномних Anelloviridae і некласифікований РНК-геномний 
pid Deltavirus не входять до жодного регіону. Родина Birnaviridae не класифікована в межах иарства Оrthогпауіraе. Родина ДНКгеномних Нераdnaviridaе включена до регіону РНК-вмісних вірусів Riboviria на підставі того, шзо реплікачія гепаднавірусів відбувається через стадію РНК за принципом зворотної транскрипиї, як і в родини Retroviridaе. Описано основні таксономічні ознаки ДНК- і РНК-геномних вірусів хребетних: тип і структура вірусного геному (ДНК або РНК, кількість ниток, конформація, фрагментованість, полярність), форма і розміри віріонів, наявність зовнішньої ліпопротеїнової оболонки, тип симетрії капсиду (спіральний, ікосаедральний). Окремі родини, крім вірусів хребетних, містять віруси безхребетних і рослин, зокрема: родини Рохvігіdае, Iridoviridae, Parvoviridae, Circoviridae, Smacoviridae, Genomoviridae, Rhabdoviridae, Nyamiviridae, Peribunyaviridae, Phenuiviridae, Nairoviridae, Nodaviridae, Reoviridae i Birnaviridae - віруси комах; родини Genomoviridae, Rhabdoviridae, Phenuiviridae i Reoviridae віруси рослин; родина Nyamiviridae - віруси нематод, иестод, сипункулідів і голкошкірих; родина Rhabdoviridaе - віруси нематод; родина Reoviridae - реовірус китайських мохноруких крабів; родина Birnaviridaе - віруси телін і коловерток.

Ключові слова: віруси, таксономія, таксономічні ранги та ознаки, ДНК-геномні, РНК-геномні, МКТВ.

\section{Вступ}

Базові засади сучасної таксономії вірусів закладено в 1966 р. на IX Міжнародному мікробіологічному конгресі (Москва). На цьому конгресі створено Міжнародний комітет із номенклатури вірусів, який iз 1973 р. перейменовано в Міжнародний комітет із таксономії вірусів (МКТВ). Комітет прийняв за основу фізико-хімічні критерії таксономії вірусів, запропоновані французькими науковцями А. Львовом та ін. у 1962 р., проте вирішив створювати таксономію вірусів поступово в міру накопичення достатньої інформації. У період 1966-1970 рр. сформовано роди вірусів, у 1971-1975 pp. - родини і підродини. Починаючи з 1990 р., окремі родини вірусів зі схожою організацією геному та єдиним механізмом реплікації об'єднано в порядки. У 2018-2019 рр. для РНК- і ДНК-геномних вірусів створено нові таксони (таксономічні ранги): регіони, царства, типи, класи, а для РНК-геномних вірусів, окрім того, - підтипи, підпорядки, підроди. Віруси належать до домену Viruses.

Сучасна таксономія вірусів $є$ універсальною для понад 4400 видів вірусів хребетних, безхребетних, рослин, грибів, найпростіших, бактерій та архей. Вона грунтується на фундаментальних властивостях вірусів, 3 яких провідними є тип і структура вірусного геному, механізм реплікації та морфологія віріона.

Для впорядкування найменувань як таксономічних рангів, так і окремих видів вірусів, МКТВ виробив певні правила. Номенклатура $є$ міжнародною та універсальною для всіх вірусів. Назва регіону закінчується на "viria", царства - “virae", типу - "viricota", підтипу - "viricotina”, класу - "viricetes”, порядку "virales”, підпорядку - “virineae”, родини - “viridae”, підродини - “virinae”, роду і підроду - “virus”. У видових назвах вірусів не було єдиного принципу: їм давали назви хвороб, імена дослідників, географічні найменування, буквені скорочення. 31998 р. МКТВ поступово запроваджує в офіційних видових назвах вірусів біномінальну номенклатуру (англійську, частково латинізовану).

Згідно з інформацією МКТВ 2020 р., віруси хребетних (1878 видів) входять до 4 регіонів, 5 царств, 10 типів, 2 підтипів, 20 класів, 26 порядків, 3 підпорядків, 45 родин (з яких 15 - ДНК-геномні та 30 - РНКгеномні), 33 підродин, 345 родів і 49 підродів. Родина ДНК-геномних Anelloviridae (14 родів, 76 видів) і некласифікований РНК-геномний рід Deltavirus (1 вид) не входять до жодного регіону. Родина Birnaviridae не класифікована в межах царства Orthornavirae. Родина ДНК-геномних Hepadnaviridae включена до регіону РНК-вмісних вірусів Riboviria на підставі того, що реплікація гепаднавірусів відбувається через стадію РНК за принципом зворотної транскрипції, як і в родини Retroviridae. Окремі родини, крім вірусів хребетних, містять віруси безхребетних і рослин, зокрема: родини Poxviridae, Iridoviridae, Parvoviridae, Circoviridae, Smacoviridae, Genomoviridae, Rhabdoviridae, Nyamiviridae, Peribunyaviridae, Phenuiviridae, Nairoviridae, Nodaviridae, Reoviridae i Birnaviridae - віруси комах; родини Genomoviridae, Rhabdoviridae, Phenuiviridae i Reoviridae - віруси рослин; родина Nyamiviridae - віруси нематод, цестод, сипункулідів і голкошкірих; родина Rhabdoviridae віруси нематод; родина Reoviridae - реовірус китайських мохноруких крабів; родина Birnaviridae віруси телін і коловерток.

\section{Результати та їх обговорення}

Таксономічні ранги вірусів хребетних наведено в табл. 1 і 2, а таксономічні ознаки родин - на рис. 1 і 2 та в табл. 3 і 4 (за інформацією МКТВ випуску 07.2019 р., ратифікація 03.2020 р.).

\section{Таблиця 1}

Таксономічні ранги ДНК-геномних вірусів хребетних

\begin{tabular}{|c|c|c|c|}
\hline Типи & Класи & Порядки & $\begin{array}{c}\text { Родини, кількість підродин, } \\
\text { родів і видів } \\
\end{array}$ \\
\hline \multicolumn{4}{|c|}{ Домен Viruses } \\
\hline \multicolumn{4}{|c|}{ Регіон Duplodnaviria } \\
\hline \multicolumn{4}{|c|}{ Царство Heunggongvirae } \\
\hline \multirow{2}{*}{ Peploviricota } & \multirow{2}{*}{ Herviviricetes } & \multirow{2}{*}{ Herpesvirales } & $\begin{array}{l}\text { Herpesviridae } \\
3 \text { підродини, } 13 \text { родів, } 107 \text { видів }\end{array}$ \\
\hline & & & $\begin{array}{l}\text { Alloherpesviridae } \\
4 \text { роди, } 13 \text { видів }\end{array}$ \\
\hline
\end{tabular}


Регіон Varidnaviria

Царство Bamfordvira

\begin{tabular}{|c|c|c|c|}
\hline \multicolumn{4}{|c|}{ Царство Bamfordvira } \\
\hline \multirow{3}{*}{ Nucleocytoviricota } & Megaviricetes & Pimascovirales & $\begin{array}{l}\text { Iridoviridae } \\
1 \text { підродина, } 3 \text { роди, } 11 \text { видів }\end{array}$ \\
\hline & \multirow{2}{*}{ Pokkesviricetes } & Asfuvirales & $\begin{array}{l}\text { Asfarviridae } \\
1 \text { рід, } 1 \text { вид }\end{array}$ \\
\hline & & Chitovirales & $\begin{array}{l}\text { Poxviridae } \\
1 \text { підродина, } 18 \text { родів, } 52 \text { види }\end{array}$ \\
\hline Preplasmiviricota & Tectiliviricetes & Rowavirales & $\begin{array}{l}\text { Adenoviridae } \\
5 \text { родів, } 80 \text { видів }\end{array}$ \\
\hline \multicolumn{4}{|c|}{ Регіон Monodnaviria } \\
\hline \multicolumn{4}{|c|}{ Царство Shotokuvirae } \\
\hline \multirow{3}{*}{ Cossaviricota } & Insthoviricetes & Zurhausenvirales & $\begin{array}{l}\text { Papillomaviridae } \\
2 \text { підродини, } 53 \text { роди, } 133 \text { види } \\
\end{array}$ \\
\hline & Papovaviricetes & Sepolyvirales & $\begin{array}{l}\text { Polyomaviridae } \\
4 \text { роди, } 102 \text { види }\end{array}$ \\
\hline & Quintoviricetes & Piccovirales & $\begin{array}{l}\text { Parvoviridae } \\
1 \text { підродина, } 10 \text { родів, } 77 \text { видів }\end{array}$ \\
\hline \multirow{4}{*}{ Cressdnaviricota } & \multirow{3}{*}{ Arfiviricetes } & Cirlivirales & $\begin{array}{l}\text { Circoviridae } \\
2 \text { роди, } 80 \text { видів }\end{array}$ \\
\hline & & Cremevirales & $\begin{array}{l}\text { Smacoviridae } \\
5 \text { родів, } 40 \text { видів }\end{array}$ \\
\hline & & Recrevirales & $\begin{array}{l}\text { Redondoviridae } \\
1 \text { рід, } 2 \text { види }\end{array}$ \\
\hline & Repensiviricetes & Geplafuvirales & $\begin{array}{l}\text { Genomoviridae } \\
8 \text { родів, } 61 \text { вид }\end{array}$ \\
\hline
\end{tabular}

Таблиця 2

Таксономічні ранги РНК-геномних вірусів хребетних

\begin{tabular}{|c|c|c|c|}
\hline Типи, підтипи & Класи & Порядки, підпорядки & $\begin{array}{c}\text { Родини, кількість підродин, родів, підродів } \\
\text { і видів }\end{array}$ \\
\hline \multicolumn{4}{|c|}{ Домен Viruses } \\
\hline \multicolumn{4}{|c|}{ Pегion Riboviria } \\
\hline \multicolumn{4}{|c|}{ Царство Orthornavirae } \\
\hline Duplornaviricota & Resentoviricetes & Reovirales & $\begin{array}{l}\text { Reoviridae } \\
2 \text { підродини, } 6 \text { родів, } 55 \text { видів }\end{array}$ \\
\hline \multirow{5}{*}{ Kitrinoviricota } & \multirow{3}{*}{ Alsuviricetes } & \multirow{2}{*}{ Hepelivirales } & $\begin{array}{l}\text { Hepeviridae } \\
2 \text { роди, } 5 \text { видів }\end{array}$ \\
\hline & & & $\begin{array}{l}\text { Matonaviridae } \\
1 \text { рід, } 1 \text { вид }\end{array}$ \\
\hline & & Martellivirales & $\begin{array}{l}\text { Togaviridae } \\
1 \text { рід, } 31 \text { вид }\end{array}$ \\
\hline & Flasuviricetes & Amarillovirales & $\begin{array}{l}\text { Flaviviridae } \\
4 \text { роди, } 89 \text { видів }\end{array}$ \\
\hline & Magsaviricetes & Nodamuvirales & $\begin{array}{l}\text { Nodaviridae } \\
2 \text { роди, } 5 \text { видів }\end{array}$ \\
\hline \multirow{7}{*}{$\begin{array}{l}\text { Negarnaviricota } \\
\text { Пidmun } \\
\text { Haploviricotina }\end{array}$} & \multirow{7}{*}{ Monjiviricetes } & \multirow{7}{*}{ Mononegavirales } & $\begin{array}{l}\text { Paramyxoviridae } \\
4 \text { підродини, } 17 \text { родів, } 77 \text { видів }\end{array}$ \\
\hline & & & $\begin{array}{l}\text { Pneumoviridae } \\
2 \text { роди, } 5 \text { видів }\end{array}$ \\
\hline & & & $\begin{array}{l}\text { Rhabdoviridae } \\
12 \text { родів, } 87 \text { видів }\end{array}$ \\
\hline & & & $\begin{array}{l}\text { Filoviridae } \\
6 \text { родів, } 11 \text { видів }\end{array}$ \\
\hline & & & $\begin{array}{l}\text { Bornaviridae } \\
3 \text { роди, } 11 \text { видів }\end{array}$ \\
\hline & & & $\begin{array}{l}\text { Nyamiviridae } \\
1 \text { рід, } 3 \text { види }\end{array}$ \\
\hline & & & $\begin{array}{l}\text { Sunviridae } \\
1 \text { рід, } 1 \text { вид }\end{array}$ \\
\hline \multirow[b]{2}{*}{$\begin{array}{l}\text { Midmun } \\
\text { Polyploviricotina }\end{array}$} & \multirow{2}{*}{ Ellioviricetes } & \multirow{2}{*}{ Bunyavirales } & $\begin{array}{l}\text { Arenaviridae } \\
4 \text { роди, } 50 \text { видів }\end{array}$ \\
\hline & & & $\begin{array}{l}\text { Peribunyaviridae } \\
2 \text { роди, } 93 \text { види }\end{array}$ \\
\hline
\end{tabular}




\begin{tabular}{|c|c|c|c|}
\hline & & & $\begin{array}{l}\text { Hantaviridae } \\
4 \text { підродини, } 7 \text { родів, } 48 \text { видів }\end{array}$ \\
\hline & & & $\begin{array}{l}\text { Nairoviridae } \\
1 \text { рід, } 15 \text { видів }\end{array}$ \\
\hline & & & $\begin{array}{l}\text { Phenuiviridae } \\
3 \text { роди, } 84 \text { види }\end{array}$ \\
\hline & \multirow{2}{*}{ Insthoviricetes } & \multirow{2}{*}{ Articulavirales } & $\begin{array}{l}\text { Orthomyxoviridae } \\
7 \text { родів, } 9 \text { видів }\end{array}$ \\
\hline & & & $\begin{array}{l}\text { Amnoonviridae } \\
1 \text { рід, } 1 \text { вид }\end{array}$ \\
\hline \multirow{8}{*}{ Pisuviricota } & Duplopiviricetes & Durnavirales & $\begin{array}{l}\text { Picobirnaviridae } \\
1 \text { рід, } 3 \text { види }\end{array}$ \\
\hline & \multirow{6}{*}{ Pisoniviricetes } & Nidovirales & $\begin{array}{l}\text { Arteriviridae } \\
6 \text { підродин, } 13 \text { родів, } 11 \text { підродів, } 23 \text { види }\end{array}$ \\
\hline & & $\begin{array}{l}\text { підпорядок } \\
\text { Arnidovirineae }\end{array}$ & $\begin{array}{l}\text { Olifoviridae } \\
1 \text { підродина, } 1 \text { рід, } 1 \text { вид }\end{array}$ \\
\hline & & $\begin{array}{l}\text { підпорядок } \\
\text { Cornidovirineae }\end{array}$ & $\begin{array}{l}\text { Coronaviridae } \\
2 \text { підродини, } 5 \text { родів, } 26 \text { підродів, } 46 \text { видів }\end{array}$ \\
\hline & & $\begin{array}{l}\text { підпорядок } \\
\text { Tornidovirineae }\end{array}$ & $\begin{array}{l}\text { Tobaniviridae } \\
4 \text { підродини, } 8 \text { родів, } 12 \text { підродів, } 15 \text { видів }\end{array}$ \\
\hline & & \multirow{2}{*}{ Picornavirales } & $\begin{array}{l}\text { Picornaviridae } \\
63 \text { роди, } 147 \text { видів }\end{array}$ \\
\hline & & & $\begin{array}{l}\text { Caliciviridae } \\
11 \text { родів, } 13 \text { видів }\end{array}$ \\
\hline & Stelpaviricetes & Stellavirales & $\begin{array}{l}\text { Astroviridae } \\
2 \text { роди, } 22 \text { види }\end{array}$ \\
\hline- & \multirow[t]{2}{*}{-} & - & $\begin{array}{l}\text { Birnaviridae } \\
3 \text { роди, } 5 \text { видів }\end{array}$ \\
\hline \multirow{3}{*}{ Artverviricota } & & Царство Parar & \\
\hline & \multirow{2}{*}{ Revtraviricetes } & Blubervirales & $\begin{array}{l}\text { Hepadnaviridae } \\
2 \text { роди, } 18 \text { видів }\end{array}$ \\
\hline & & Ortervirales & $\begin{array}{l}\text { Retroviridae } \\
2 \text { підродини, } 11 \text { родів, } 68 \text { видів }\end{array}$ \\
\hline
\end{tabular}

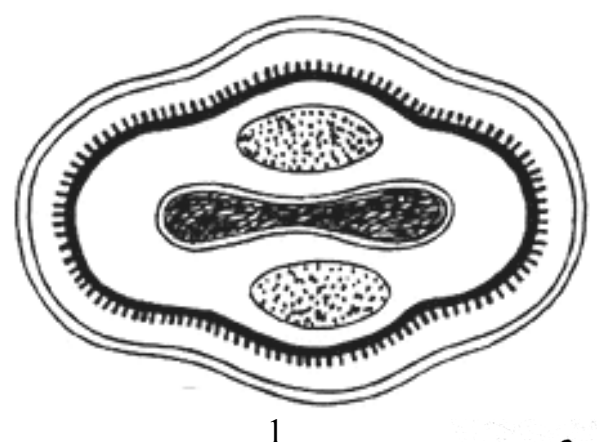

1

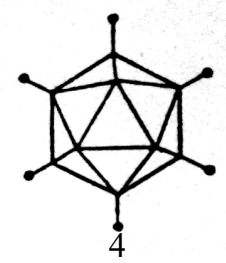

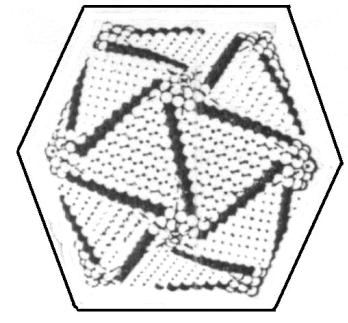

2

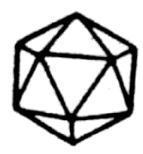

5

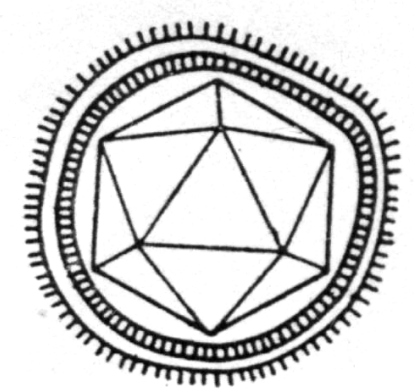

3

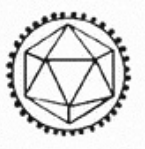

6

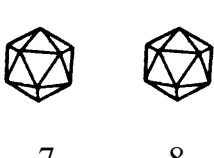

Рис. 1. Структура ДНК-геномних вірусів хребетних:

1 - поксвіруси; 2 - асфарвіруси, ірідовіруси; 3 - герпесвіруси, аллогерпесвіруси; 4 - аденовіруси; 5 - папіломавіруси, поліомавіруси; 6 - гепаднавіруси; 7 - парвовіруси; 8 - цирковіруси, анелловіруси, смаковіруси, геномовіруси,

редондовіруси 

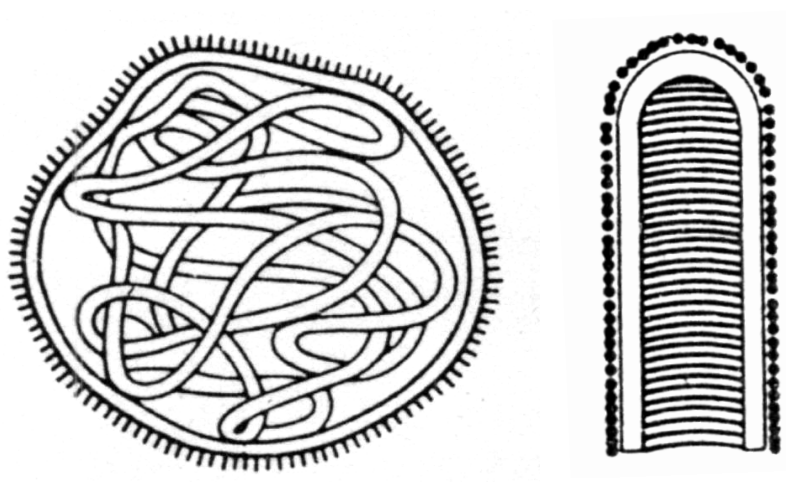

2

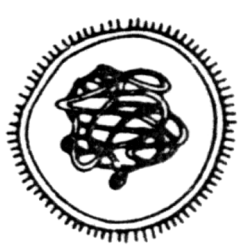

7

1

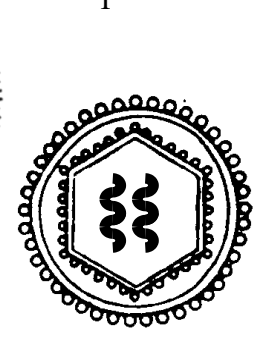

12

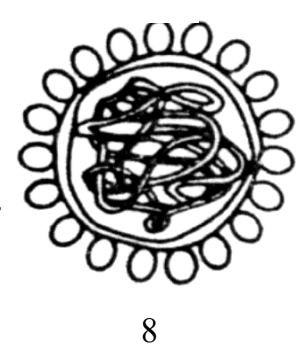

8
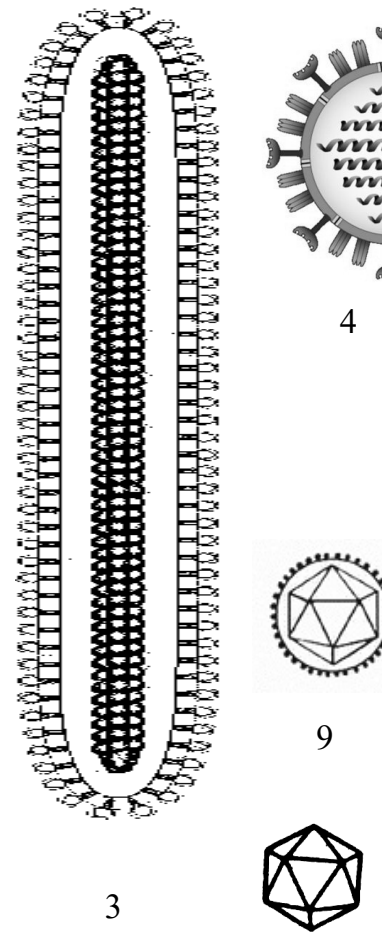

13
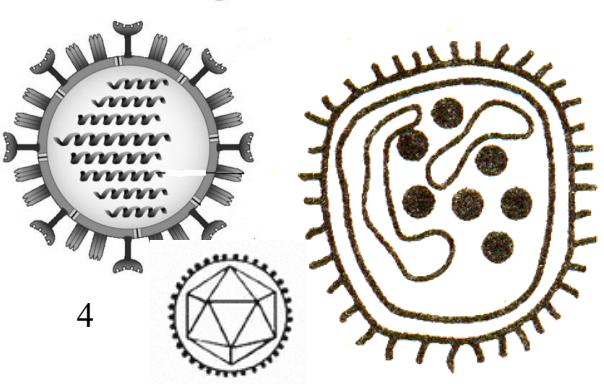

5

6

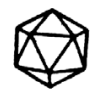

10

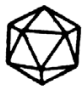

11

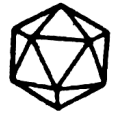

(m)

14

Рис. 2. Структура РНК-геномних вірусів хребетних:

1 - параміксовіруси, пневмовіруси, борнавіруси, ньямівіруси, сунвіруси; 2 - рабдовіруси; 3 - філовіруси;

4 - ортоміксовіруси; 5 - амноонвіруси; 6 -аренавіруси; 7 - перібун'явіруси, хантавіруси, найровіруси, фенуївіруси; 8 - коронавіруси, тобанвіруси; 9 - артерівіруси, тогавіруси, флавівіруси, матонавіруси, оліфовіруси; 10 - пікорнавіруси, каліцівіруси, астровіруси, гепевіруси; 11 - нодавіруси; 12 - ретровіруси; 13 - реовіруси; 14 - бірнавіруси, пікобірнавіруси; 15 - дельтавірус.

\section{Таблиця 3}

Основні таксономічні ознаки ДНК-геномних вірусів хребетних

\begin{tabular}{|c|c|c|c|c|c|c|}
\hline \multirow[b]{2}{*}{ Родина } & \multicolumn{2}{|c|}{ ДНК } & \multirow[b]{2}{*}{ Форма віріона } & \multirow{2}{*}{$\begin{array}{c}\text { Розміри } \\
\text { віріона } \\
\text { (нм) }\end{array}$} & \multirow{2}{*}{$\begin{array}{c}\text { Зовнішня } \\
\text { ліпопротеїнова } \\
\text { оболонка }\end{array}$} & \multirow{2}{*}{$\begin{array}{l}\text { Тип симетрії } \\
\text { капсиду }\end{array}$} \\
\hline & $\begin{array}{c}\text { Струк- } \\
\text { тура }\end{array}$ & $\begin{array}{c}\text { Поляр- } \\
\text { ність }\end{array}$ & & & & \\
\hline Poxviridae (поксвіруси) & $2 \mathrm{H}(л)$ & & $\begin{array}{c}\text { Цеглиноподібна, } \\
\text { овоїдна }\end{array}$ & $\begin{array}{l}300-450 \times \\
170-260\end{array}$ & $\epsilon$ & - \\
\hline Asfarviridae (асфарвіруси) & 2н (л) & & $\begin{array}{c}\text { Сферична, } \\
\text { ікосаедральна }\end{array}$ & $175-215$ & $\epsilon$ & Ікосаедральний \\
\hline Iridoviridae (ірідовіруси) & 2н (л) & & $\begin{array}{l}\text { Ікосаедральна, } \\
\text { сферична }\end{array}$ & $\begin{array}{c}120-200 \\
\text { до } 350\end{array}$ & $\begin{array}{l}\text { Немає, } \\
\epsilon\end{array}$ & Ікосаедральний \\
\hline Herpesviridae (герпесвіруси) & 2н (л) & & Сферична & $85-300$ & $\epsilon$ & Ікосаедральний \\
\hline Alloherpesviridae (аллогерпесвіруси) & 2н (л) & & Сферична & $150-200$ & $\epsilon$ & Ікосаедральний \\
\hline Adenoviridae (аденовіруси) & 2н (л) & & Ікосаедральна & $70-90$ & Немає & Ікосаедральний \\
\hline Papillomaviridae (папіломавіруси) & $2 \mathrm{H}(\kappa)$ & & Ікосаедральна & 55 & Немає & Ікосаедральний \\
\hline Polyomaviridae (поліомавіруси) & $2 \mathrm{H}(\kappa)$ & & Ікосаедральна & $40-45$ & Немає & Ікосаедральний \\
\hline Hepadnaviridae (гепаднавіруси) & $2 \mathrm{H}(\kappa)$ & & Сферична & $42-47$ & E & Ікосаедральний \\
\hline Parvoviridae (парвовіруси) & $1 \mathrm{H}(л)$ & $-\mathrm{i}+$ & Ікосаедральна & $18-26$ & Немає & Ікосаедральний \\
\hline Circoviridae (цирковіруси) & $1 \mathrm{H}(\kappa)$ & - & Ікосаедральна & $15-25$ & Немає & Ікосаедральний \\
\hline Anelloviridae (анелловіруси) & $1 \mathrm{H}(\kappa)$ & - & Ікосаедральна & $30-32$ & Немає & Ікосаедральний \\
\hline Smacoviridae (смаковіруси) & $1 \mathrm{H}(\kappa)$ & - & Ікосаедральна & Н.д. & Немає & Ікосаедральний \\
\hline Genomoviridae (геномовіруси) & $1 \mathrm{H}(\kappa)$ & - & Сферична & 20 & Немає & Ікосаедральний \\
\hline Redondoviridae (редондовіруси) & $1 \mathrm{H}(\kappa)$ & - & Ікосаедральна & Н.д. & Немає & Ікосаедральний \\
\hline
\end{tabular}


Таблиця 4

Основні таксономічні ознаки РНК-геномних вірусів хребетних

\begin{tabular}{|c|c|c|c|c|c|c|}
\hline \multirow[b]{2}{*}{ Родина } & \multicolumn{2}{|c|}{ PHK } & \multirow[b]{2}{*}{ Форма віріона } & \multirow{2}{*}{$\begin{array}{c}\text { Розміри } \\
\text { віріона } \\
\text { (нм) }\end{array}$} & \multirow{2}{*}{$\begin{array}{c}\text { Зовнішня } \\
\text { ліпопротеїнова } \\
\text { оболонка }\end{array}$} & \multirow[b]{2}{*}{$\begin{array}{c}\text { Тип симетрії } \\
\text { капсиду }\end{array}$} \\
\hline & $\begin{array}{l}\text { Струк- } \\
\text { тура }\end{array}$ & $\begin{array}{c}\text { Поляр- } \\
\text { ність }\end{array}$ & & & & \\
\hline $\begin{array}{l}\text { Paramyxoviridae } \\
\text { (параміксовіруси) }\end{array}$ & 1н (л) & - & $\begin{array}{l}\text { Плеоморфна, } \\
\text { сферична }\end{array}$ & $120-350$ & $\epsilon$ & Спіральний \\
\hline $\begin{array}{l}\text { Pneumoviridae } \\
\text { (пневмовіруси) }\end{array}$ & 1н (л) & - & $\begin{array}{l}\text { Сферична, } \\
\text { ниткоподібна }\end{array}$ & $\begin{array}{c}80-140 \\
250-600 \\
2000 \times \\
70-190\end{array}$ & $\epsilon$ & Спіральний \\
\hline $\begin{array}{l}\text { Rhabdoviridae } \\
\text { (рабдовіруси) }\end{array}$ & 1н (л) & - & Кулеподібна & $\begin{array}{c}130-380 \times \\
60-80\end{array}$ & $\epsilon$ & Спіральний \\
\hline Filoviridae (філовіруси) & 1н (л) & - & $\begin{array}{l}\text { Плеоморфна, } \\
\text { ниткоподібна }\end{array}$ & $\begin{array}{c}790,970 \\
\text { або } 1400 \times 80\end{array}$ & $\epsilon$ & Спіральний \\
\hline Bornaviridae (борнавіруси) & 1л (л) & - & Сферична & $80-100$ & $\epsilon$ & Спіральний \\
\hline Nyamiviridae (н'ямівіруси) & $1 н$ (л) & - & Сферична & $100-130$ & $\epsilon$ & Спіральний \\
\hline Sunviridae (сунвіруси) & $1 н$ (л) & - & Сферична & Н.д. & $\epsilon$ & Спіральний \\
\hline $\begin{array}{l}\text { Orthomyxoviridae } \\
\text { (ортоміксовіруси) }\end{array}$ & $1 \mathrm{H}(\phi)$ & - & $\begin{array}{l}\text { Плеоморфна, } \\
\text { сферична }\end{array}$ & $80-120$ & $\epsilon$ & Спіральний \\
\hline $\begin{array}{l}\text { Amnoonviridae } \\
\text { (амноонвіруси) }\end{array}$ & 1 н $(\phi)$ & - & Сферична & $55-100$ & $\epsilon$ & Ікосаедральний \\
\hline Arenaviridae (аренавіруси) & 1н (фк) & - & $\begin{array}{l}\text { Плеоморфна, } \\
\text { сферична }\end{array}$ & $50-300$ & $\epsilon$ & Спіральний \\
\hline $\begin{array}{l}\text { Peribunyaviridae } \\
\text { (перібун'явіруси) }\end{array}$ & 1н (фк) & - & Сферична & $80-120$ & $\epsilon$ & Спіральний \\
\hline Hantaviridae (хантавіруси) & 1н (фк) & - & Сферична & $80-120$ & $\epsilon$ & Спіральний \\
\hline Nairoviridae (найровіруси) & 1н (фк) & - & Сферична & $80-120$ & $\epsilon$ & Спіральний \\
\hline Phenuiviridae (фенуївіруси) & 1н (фк) & - & Сферична & $80-120$ & $\epsilon$ & Спіральний \\
\hline $\begin{array}{l}\text { Coronaviridae } \\
\text { (коронавіруси) }\end{array}$ & 1н (л) & + & $\begin{array}{l}\text { Плеоморфна, } \\
\text { сферична }\end{array}$ & $80-220$ & $\epsilon$ & Спіральний \\
\hline Tobaniviridae (тобанвіруси) & 1н (л) & + & $\begin{array}{l}\text { Плеоморфна, } \\
\text { сферична }\end{array}$ & $120-140$ & $\epsilon$ & Спіральний \\
\hline Arteriviridae (артерівіруси) & $1 н$ (л) & + & Сферична & $50-70$ & $\epsilon$ & Ікосаедральний \\
\hline Togaviridae (тогавіруси) & $1 н$ (л) & + & Сферична & $65-70$ & $\epsilon$ & Ікосаедральний \\
\hline Flaviviridae (флавівіруси) & 1 н (л) & + & Сферична & $40-60$ & $\epsilon$ & Ікосаедральний \\
\hline $\begin{array}{l}\text { Matonaviridae } \\
\text { (матонавіруси) }\end{array}$ & 1н (л) & + & Сферична & $50-70$ & $\epsilon$ & Ікосаедральний \\
\hline Olifoviridae (оліфовіруси) & 1н (л) & + & Сферична & Н.д. & $\epsilon$ & Ікосаедральний \\
\hline $\begin{array}{l}\text { Picornaviridae } \\
\text { (пікорнавіруси) }\end{array}$ & 1н (л) & + & Сферична & $20-32$ & Немає & Ікосаедральний \\
\hline Caliciviridae (каліцівіруси) & 1н (л) & + & $\begin{array}{c}\text { Сферична, } \\
\text { ікосаедральна }\end{array}$ & $27-40$ & Немає & Ікосаедральний \\
\hline Astroviridae (астровіруси) & 1н (л) & + & Сферична & $28-30$ & Немає & Ікосаедральний \\
\hline Hepeviridae (гепевіруси) & $1 \mathrm{H}(л)$ & + & Сферична & $27-34$ & Немає & Ікосаедральний \\
\hline Nodaviridae (нодавіруси) & $1 \mathrm{H}(\phi)$ & + & Сферична & $25-35$ & Немає & Ікосаедральний \\
\hline Retroviridae (ретровіруси) & 1н (л) & + & Сферична & $80-100$ & $\epsilon$ & Ікосаедральний \\
\hline Reoviridae (реовіруси) & $2 \mathrm{H}(\phi)$ & & Сферична & $60-80$ & Немає & Ікосаедральний \\
\hline Birnaviridae (бірнавіруси) & $2 \mathrm{H}(\phi)$ & & Ікосаедральна & $60-70$ & Немає & Ікосаедральний \\
\hline $\begin{array}{l}\text { Picobirnaviridae } \\
\text { (пікобірнавіруси) }\end{array}$ & $2 \mathrm{H}(\phi)$ & & Сферична & $33-37$ & Немає & Ікосаедральний \\
\hline Deltavirus (дельтавірус) & $1 \mathrm{H}(\kappa)$ & - & Сферична & $36-43$ & $\epsilon$ & - \\
\hline
\end{tabular}

\section{Висновки}

Сучасний етап у таксономії вірусів характеризується формуванням нових таксономічних рангів. Віруси хребетних (1878 видів) входять до домену Viruses, 4 регіонів, 5 царств, 10 типів, 2 підтипів, 20 класів, 26 порядків, 3 підпорядків, 45 родин (з яких 15 - ДНК-геномні та 30 - РНК-геномні), 33 підродин, 345 родів і 49 підродів.

\section{References}

Virus Taxonomy: 2019 Release International Committee on Taxonomy of Viruses [Electronic resourse]. Mode of acces: https://talk.ictvonline.org/taxonomy. 